\title{
ELECTORAL VIOLENCE AND ITS INSTRUMENTAL LOGIC: Mapping Press Discourse on Electoral Violence during Parliamentary and Presidential Elections in Zimbabwe
}

\author{
Tendai Joseph Chari \\ Tendai Joseph Chari is a Doctoral Candidate at the University of the \\ Witwatersrand, Johannesburg \\ email: tendai.chair@yahoo.com
}

\begin{abstract}
Elections are one of the key benchmarks for assessing the international perception of a nation's democratic credentials. However, the credibility of elections is increasingly being tied to questions of whether or not they are conducted in a peaceful atmosphere. Where violence exists as part of the menu of manipulation the press becomes a crucial tool for shaping public perceptions about electoral legitimacy or lack thereof. This study employed a Foucauldian discursive approach to the analysis of election violence in two state-owned newspapers, namely The Herald and The Sunday Mail, and three privately-owned newspapers, namely The Zimbabwe Independent, The Financial Gazette, and the Daily News. Empirical data were drawn from a corpus of news stories published during the 2000 parliamentary and the 2002 presidential elections. The article argues that press construction of election violence was marked by competing discourses reflecting political and ideological bifurcation and this gave way to anti-democratic discursive strategies which could engender political intolerance among the citizenry.
\end{abstract}

\section{INTRODUCTION}

Zimbabwe has held regular elections since the country became independent from Britain in 1980. However, elections held after 2000 were unique in that the ruling party, the Zimbabwe African National Union Patriotic Front (Zanu-PF), which had previously enjoyed dominance, faced fierce competition from the newly formed 
opposition party, the Movement for Democratic Change (MDC). In the ensuing political contestation the national press became a site for competing regimes of truth in relation to election violence. The state-owned press unapologetically defended the ruling party position while the privately-owned press rooted for the opposition. The partisan way in which the press reported was such that the precise meaning of election violence, its scale, the perpetrators and victims and its impact on electoral outcomes, were contingent upon the press that reported on it at any given moment.

Theoretically underpinned by Michel Foucault's discourse theory, this article examines the discursive construction of electoral violence in the Zimbabwean press during the 2000 parliamentary and the 2002 presidential elections in order to gain deeper insights into the actual role of the press in electoral conflicts. The principal question addressed in this article is: how did the press construct election violence and why did it construct election violence that way? The article further reflects on the wider implications of these discourses on democracy. The Foucauldian conception views discourse as embedded in relations of power in so far as it entails the reproduction of a particular regime of truth and knowledge distributed through text and talk. Understood this way discourse is viewed as a representation of versions of reality whereby meanings are ascribed, rather than having intrinsic meaning. Through its framing practices, the press therefore plays a crucial role in shaping citizen perceptions and attitudes about election violence.

The article argues that both the state-owned and the privately-owned press in Zimbabwe produced competing discourses about electoral violence, pitting a 'national interest' discourse against a 'liberal human rights' discourse respectively. These discourses demonstrate the instrumental logic of electoral violence whereby the press becomes a weapon for capturing or retaining power through an accentuation of particular discourses of election violence. The article posits that the discursive construction of electoral violence by the press in Zimbabwe constitute more than the mere existence of distinct regimes of truth by ideologically incompatible press groups. Instead, it signifies a press at the service of power rather than of democracy. The absolute morality imbued in discourses on election violence have the potential to engender anti-democratic practices and a political culture of intolerance in society, particularly in fragile societies bedevilled by social and political divisions. By asserting their discursive power through accentuating particular versions of election violence while suppressing others, the press in Zimbabwe became hostages of political power structures, thereby undermining democracy. The polarising discursive practices employed by the press present an opportunity to gain deeper insights into how the press can engender anti-democratic practices, political culture and intolerance. As Floss (2008, p. 4) notes, a society's political culture is gauged by the character of 
its institutions, practices and rationalities, and the press is one of the most critical institutions through which political cultures, values, and practices are instilled among the citizens.

The remainder of this article is divided into four parts. Part one contains a brief discussion of the literature on media and election violence and situates the research questions about the press and election violence in an appropriate context. This section also discusses the conceptual framework which underpins this article, namely Foucauldian discourse, and how it links up with the literature and the methodology. Part two outlines the methodology of the study, focusing on methods of data collection and analysis. Part three discusses the press discourses on election violence based on the themes emerging from the data. Part four is the conclusion and reflects on press discourses on electoral violence and their wider implications for democracy in Africa.

\section{THE PRESS AND ELECTION VIOLENCE: MEDIATING THE MENU OF MANIPULATION}

There is an expansive literature on media coverage of political violence in its broad sense, encompassing demonstrations, protests, insurgencies, and terrorism (Schlesinger 1991; Miller 1992, Nossek et al. 2002, Ismail \& Dean 2007, Hobart 2007; Stremlau et al. 2009). However, it is troubling to know that very little academic enterprise has been expended on examining election violence per se, given the fact that elections in Africa are increasingly punctuated by violence (see Khadiagala 2009; Koko 2010; Merilainen 2012; Motsamai 2010; Shilaho 2013). An understanding of how the media, particularly the press, is implicated in electoral conflicts in Africa is imperative in understanding how the press can either enhance or hinder electoral democracy in Africa. How the media construct meaning about election violence, and how such constructions impact on public perceptions and attitudes is a matter of conjecture. The liberal democratic perception of the media is that it has a crucial role in shaping public opinion and insight into the legitimacy or lack thereof of elections through their framing practices. However, there appears to be a mismatch between the normative ideals of the press and its practice. It is becoming increasingly clear that the wholesale application of the liberal AngloAmerican democratic model, with its one-size-fits-all approach, is no longer tenable in the non-western context (Berger 2002; Hallin \& Mancin 2004; Shaw 2009). Vladiasvlievic $(2015$, p. 1) argues that there is need to develop new theories that are more suitable for discerning the role that the media plays in democratisation. There are more compelling reasons for charting a research agenda around the media and elections in weak and fragile states. This is particularly true in Africa, against the backdrop of increasing election violence in recent times, forcing some scholars to view elections as a curse (Motsamai 2010, p. 1). 
Notable cases of election violence include the Ivorian 2010/2011 post-election violence in which 3000 people died, the 2007/2008 post-election violence in Kenya, and the 2008 election violence in Guinea Bissau. Of these, only the Kenyan 2007/2008 post-election violence has received considerable scholarly attention (Anderson 2002; Smedt 2009; Khadiagala 2009; Koko 2010; Merilainen 2012; Shilaho 2013). However, the tendency has been a wholesale blame of the media for the election violence, thereby masking the real role of the media in this context and prematurely closing the debate on the nexus between the media and election violence.

There are few studies that directly address the role of the press in election violence in the African context. Of these a significant number focus on the role of the press in the Kenyan post- election violence of 2007/2008, while no studies exist on the bloodiest electoral conflict on the African continent, the 2010/2011 Ivorian elections. Notable studies on the Kenyan conflict include Onyebadi and Oyedeji's (2011) content analytic examination of how the country's main newspapers, the Daily Nation and The Standard, covered the post-election violence. Onyebadi and Oyedeji argue that the way in which the two newspapers reported on the postelection crisis in Kenya advanced peace rather than conflict, thereby debunking the 'stereotypical characterization of African media as sectarian advocates of mayhem or institutions that hardly play any constructive role during crises' (Onyebadi \& Oyedeji 2011, p. 224).

The study observes that during the pre-election period these two newspapers used thematic frames to address the restoration of peace. This demonstrates that even in the context of worst-case scenarios such as the Kenyan post-election violence of 2007, the media's role is not wholly negative. Although the dominant view is that the media in Kenya, particularly the local language radio stations, were responsible for fanning violence (Ismail \& Dean, 2008, Ogola, 2009), Onyebadi and Oyedeji's study shows that the mainstream press in that country generally played a positive role by fostering peacebuilding (Onyebadi \& Oyedeji 2012). This debunks the wholesale indictment of the media's role in Kenya's 2007 postelection violence.

Although Onyebadi and Oyedeji's study is based on two newspapers with similar ownership, their study deviates from conventional wisdom about the role of the media in electoral conflicts in Africa. This supplies the impetus for further empirical studies and a rethink of the role of the press in political conflicts in fragile societies. The drawback, however, is that this was a small study which did not cover a full electoral cycle and the analysis is limited to only two newspapers. Although Onyebadi and Oyedeji illuminate the possible role of the press in election violence, their content analysis approach is limited to explicating themes rather than providing a holistic perspective on the meaning 
and value ascribed to election violence. Similarly, Coesmans (2013) studied the discursive constructions of Kenya's post-2007 election violence in hard news reports from a linguistic-pragmatic approach. His methodology encompassed quantitative content analysis, qualitative discourse analysis and ethnographic fieldwork, comparing the thematic analysis of news reports from local newspapers (Daily Nation and The Standard) and foreign newspapers (The Independent (UK), The Times, The New York Times and The Washington Post). He concluded that news representation in British and American newspapers accentuated ethnicity while that of the national newspapers tended to politicise post-election violence. $\mathrm{He}$ argued that the difference in language use is attributed to 'contextual (political, social and pragmatic) factors' (Coesmans 2013, p. 179).

This article foregrounds the production of meaning in journalistic texts (Louw 2001). It is mindful of the fact that the media are ideological tools which co-construct meaning with 'multiple players embedded in ever shifting contextual arrangements within which there are simultaneous pressures for "opening" and “closing" reading (and coding) possibilities' (Louw 2001, p. 208). While existing studies lean more towards how the media are directly implicated in electoral conflicts by inciting violence, there has been no focus on how the media are indirectly implicated in electoral conflicts through their discursive and framing practices. This is therefore a more nuanced approach to exploring discursive constructions of election violence as an alternative 'way of seeing' (Schlesinger 1991).

The key questions which this article seeks to address are: How did the press and citizens in Zimbabwe construct election violence during Zimbabwe's presidential and parliamentary elections during 2000 and 2002? What meanings do the press generate about electoral violence? Why do they construct such meanings? In order to address these questions a discursive analytic approach was adopted in order to glean insights into the way in which the press constructed election violence during presidential and parliamentary elections in Zimbabwe.

\section{Discourse, Power and Knowledge: A Foucauldian Perspective}

One key concept that spotlights the production of meaning as being embedded in power relations is that of discourse. The concept of discourse is broad and multidimensional (Pitsoe \& Letseka 2013, p. 24) and as a result scholars seldom agree on a precise definition, with some catch-all and other narrow definitions of the term, (Hobbs 2008, p. 7). Many scholars are however in agreement that the term discourse owes its origins to the works of French scholar and post-structuralist, Michel Foucault (Fairclough 1995; Chouliaraki \& Fairclough 1999; Hobbs 2008). Foucault views discourse as 'social practice' and 'a way of representing knowledge 
- about a particular topic at a particular historical moment...' (Foucault, cited in Hall 1992, p. 291). This definition is broad enough to encompass language, social practices and ways of thinking about particular subjects. Chouliraki and Fairclough subscribe to Foucault's definition of discourse but extend it to include the 'economic, social and cultural changes of late modernity' as well (Chouliaraki \& Fairclough 1999, p. 4). Conceived this way, discourse encompasses both material and extra-discursive facets of social reality such as money, power, relations, material practices, institutions, beliefs, values and modes of social relations (Chouliraki \& Fairclough 1999, p. 6). Such a definition is elastic enough to incorporate all the elements of the Foucauldian discursive approach which underpins this study.

Viewing discourse as social practice implies that when analysing discourse it is imperative to pay attention to the social conditions in which discourse is produced, consumed and interpreted. This is because discourse is constitutive, meaning it is shaped by and shapes the conditions in which it is produced. This conception of discourse is important in that it does not confine discourse to language, but incorporates ways of talking, thinking, morality, and everyday social practices that are taken for granted. This links up with the concept of political culture which informs this article, in so far as media discourse shapes the work of journalists through framing practices that affect perceptions (Hobbs 2008 , p. 7). The Foucauldian conception of discourse foregrounds the production of meaning as particular 'regimes of truth' (Foucault 1972; Hobbs 2008) distributed through text and talk, and incorporates Fairclough's idea of discourse as a social practice (Fairclough, 1995, p. 13). To the extent that journalists have the privilege to 'impart certain social truths' to citizens (Hobbs 2008, p. 11) they can predispose citizens to particular political cultural practices and attitudes. Pitsoe and Letseka (2013, p. 24) correctly assert that, 'as a social construct, discourse is created and perpetuated by those who have access to the means of communication'. The constitutive nature of discourse implies that discourse is both an effect and an instrument of power.

\section{METHODOLOGICAL CONSIDERATIONS}

This article contains a qualitative analysis of discursive constructions of presidential and parliamentary elections in Zimbabwe. It is concerned with the discursive constructions of election violence, which entail a systematic disclosure of textual meanings, thereby locating the study in the realm of social constructionism. Galbin (2014, p. 82) defines social constructionism as a 'perspective which believes that a great deal of human life exists as it does due to social and interpersonal influences'. The over-arching concern of social 
constructionism is meaning and power, concepts which lie at the heart of the Foucauldian discursive approach employed in this article. White (2000, p. 7) argues that people construct meanings according to their life experiences and contexts. Unearthing these meanings is the main task of the discourse analyst. Social constructionism rejects the positivist view that data already exists, positing that data must be uncovered. Social constructionists' belief that reality is socially constructed rather than 'merely there' (Alvesson \& Skoldberg 2009, p. 23) means that meaning has to be disclosed by pricking holes in texts. The discourse analytic approach deployed in this article lends itself to the task of 'pricking holes' in the text as it is premised on the assumption that there are different regimes of truth in relation to a particular event. The Foucauldian notion of discourse adheres to the social constructionist premise which views knowledge as a social construction rather than something that is fixed or is simply out there (Jorgensen \& Phillips 2002, p. 13). Foucault (1980, p. 119) notes that what makes power effective is that it is pervasive and produces discourse and knowledge. This view resonates with Durkheim's contention that social facts should be viewed as things (cited in Alvesson \& Skoldberg 2009, p. 25) implying that social facts need to be interrogated.

\section{DATA}

Empirical data were drawn from a corpus of purposively selected archival textual data. These comprise hard news articles published in two state-owned newspapers, namely The Herald and The Sunday Mail, and three privately-owned newspapers, namely The Zimbabwe Independent, The Financial Gazette, and the Daily News, all of which are influential sources of public opinion in Zimbabwe. In order to get a deeper appreciation of the rationale for press representation of election violence, semi-structured interviews were held with the editors of these newspapers. Thus, while the textual data sought to address the question relating to how the press discursively constructed election violence, interviews with journalists and editors sought to gain insights into the rationale for such discursive constructions. To this extent, semi-structured interviews were conducted with purposively selected journalists and editors from the newspapers selected for the study. Arksey and Knight (cited in Gray 2009, p. 370) argue that 'interviewing is a powerful way of helping people to make explicit things that have hitherto been implicit - to articulate their tacit perceptions, feelings and understandings'.

The determination of the units of analysis was influenced by the research questions and interpretative approach adopted for analysing the data, whereby important themes had to be explicated from the data. This is in order to provide descriptions of the ways in which the press and citizens construct reality 
about election violence. The main units of analysis were hard news articles as well as interview data. The data coding and organisation entailed identifying, summarising, explicating and structuring emerging themes or patterns that speak to the research questions using coding sheets, one for the textual data and another for the interview data. Analysis also involved looking for connections between conceptual categories emerging from the data, by carefully examining whether any of the concepts relate to the literature section. In order to draw meaningful conclusions from the data the author made inferences and reconstructed meanings from the data by exploring the attributes of the different data sets. Relationships between data categories were also drawn. Quotations that were considered key to addressing the research questions were incorporated in the analysis but the researcher was mindful of Patton's advice that one should 'strive for balance between description and interpretation' (cited in Zhang \& Wildemuth, n.d). The next section discusses discourses on election violence which emerged from the analysis of textual and interview data.

\section{Perpetrator and Victim Construction: The Blame Game}

The representation of election violence produced polarised versions of reality whereby the state-owned press attributed election violence to the opposition MDC, while the privately-owned press blamed the ruling Zanu-PF and the state $^{1}$. The state-owned press published a significant number of stories blaming the MDC for most of the election violence. An example of news headlines which support this include: '31 injured as MDC supporters raid Zanu (PF) candidate's home' (The Herald 19 June 2000, p. 1); 'MDC supporters assault suspected Zanu (PF) youths' (The Herald 19 June 2000 p. 5); 'MDC youths provoke violence in Hwedza: Police' (The Herald 23 June 2000, p. 5); 'MDC plans pre-election country-wide terror campaign' (The Sunday Mail 10 February 2002, p. 1); and 'MDC youths embark on terror campaign' (The Sunday Mail 24 February 2002, p. 1).

The state-owned press used numerous sobriquets which sought to blemish the image of the opposition. Thus the state-owned press constructed MDC supporters as 'thugs' (The Herald 19 June 2000, p. 5); 'mobs' (The Herald 24 June 2000, p. 1,); 'marauding gangs' (The Herald 16 June 2000, p. 1); 'rowdy' (The Herald 12 March, 2002, p. 4) or 'berserk'. This implies that the MDC was violent, criminal, bloodthirsty and destructive and hence was not worth voting for. In the state press the MDC supporters were also described as 'killers' (The Herald, 13 June 2000, p. 4 and 3 June 2000, p. 5; The Sunday Mail 8 June 2007, p. 2), and 'assassins'

1 As the economic and political crisis progressively worsened the distinction between the state and the ruling party became more and more blurred. This is largely attributable to the siege mentality occasioned by sanctions and external interference. 
(The Herald 19 June 2000, p. 10). By depicting the opposition as perpetrators and the ruling party supporters as victims of election violence, the state-owned press sought to portray the MDC as uncivilised, evil and therefore unelectable. Further, exclusively attributing the perpetration of violence to one political party might have created the impression that the opposition party deserved a brutal clampdown by law enforcement agents. This view is bolstered by the state press's claim that the MDC had introduced 'a culture of violence in Zimbabwe' (The Herald 16 March 2002, p. 1), indicating that a clampdown on the opposition was not only justified but also overdue. The Herald reasoned that the birth of the MDC brought violence to Zimbabwean politics. The Sunday Mail (6 June 2000, p. 5 ) argued that the MDC's violent streak had a long history dating as far back as the 'run up to the February (2000) referendum on the draft constitution when the MDC/NCA alliance embarked on a violent campaign to disrupt report-back meetings of the Constitutional Commission'. It was also claimed that opposition supporters were emulating their leader Morgan Tsvangirai, who 'had vowed to remove President Mugabe from power' (The Herald 27 February 2002, p. 4). This was a veiled reference to Tsvangirai's threat to remove President Mugabe 'violently' (Ferret 2000) if he did not step down voluntarily. Tsvangirai is reported to have said: 'What we would like to tell Mugabe today is that please go peacefully. If you don't want to peacefully, we will remove you violently. The country cannot afford Mugabe a day longer than necessary'. He was addressing a gathering of his supporters in Harare at the occasion of his party's first anniversary.

In order to demonstrate that the culture of election violence was alien to Zimbabwe prior to the formation of the MDC, the state-owned press claimed that Zimbabwe had held many multi-party elections since 1980 without any violence, which of course was inaccurate. Quoting the then Zanu-PF Secretary for Information and Publicity, Dr. Nathan Shamuyarira, The Herald (27 February 2002, p. 4) reported that Zimbabwe had 'been holding multi-party elections without violence'. The newspaper selectively recounted how different political parties had graced the Zimbabwean political scene in the 1990s, adding that 'there was no violence at all' during that time. Contrary to Shamuyarira's assertion, some scholars have documented the history of election violence, noting how violence has been part and parcel of the Zimbabwean electoral culture since 1980 (Sachikonye 1990; Sithole \& Makumbe 1997; Kiger, 2005). The Herald conveniently chose to gloss over this reality in order to buttress its version that election violence was a new phenomenon synonymous with the formation of the MDC. By constructing election violence as a new phenomenon in Zimbabwe, the state-owned press eliminated any possibility of a nuanced understanding of and possible remedies for this culture of violence. 
Selectivity was also demonstrated through state-owned press constructions of the opposition MDC as the exclusive perpetrator of violence and ruling party supporters as passive victims of election violence. The state-owned press selected incidences of violence in which the MDC was alleged to be the perpetrator or had endorsed violence. Blame for violence was based on the previous record of a political party rather than on the objective material facts about what was happening at the time. Caesar Zvayi, editor of the state-owned newspaper, The Herald, gave an insight on this view when he said that:

... we have seen a number of times, for instance, the MDC supporters can, they know that Zanu (PF) is holding a rally in this area, they go there to provoke a situation and then you have these correspondents, some of them who moonlight for international media take those images and send them outside world.

Caesar Zvayi, interview, 7 May, 2015, Harare

This shows that the apportionment of blame for election violence was based on a stereotypical abstraction and not what was happening at the material time. Thus, in the state-owned press, the opposition was pigeon-holed as the perpetrator and the ruling party as an innocent victim. Given the polarised state of Zimbabwean society during electoral contests, it is not possible that only one party was responsible for all election violence. As Sachikonye (2011, p. 31) observes, both the ruling party and the opposition perpetrated political violence, although their culpability may not have been the same. That the press discursively constructs election violence through the lens of an absolute morality demonstrates how the press was used to either legitimise or delegitimise elections. In the state-owned press, this instrumentality was discursively concretised by sanitising all past elections and presenting them as violence-free. At the same time they were amplifying violence in contemporary elections as a discursive strategy to justify the causal link between rising election violence and the formation of MDC. Selectivity also entailed picking and choosing particular events (such as Morgan Tsvangirai's speech at Rufaro stadium) to use as a benchmark for the opposition's violent behaviour. Such a discursive strategy dovetails with Akpabio's 'framing up' technique. This entails selecting and organising news stories so as to foster a onedimensional interpretation of events (Akpabio 2011, p. 45) in order to incriminate an opponent. Such discourses might have mobilised negative feelings against the opposition thereby exacerbating rather than reducing election violence. Akpabio (2011, p. 46) correctly observes that: '... persistent and negative framings are always a precursor to something evil'. 
A dominant way of portraying enemies is to dehumanise them thereby justifying any mistreatment meted out to them. It could be argued that through such discursive practices, the state-owned press might have created an alibi for the liquidation of the opposition. This is because discourse has consequences in that it always translates into particular action and behaviour. Steuter and Wills (2009) support this view when they observe that once an 'enemy' has been stereotyped it becomes psychologically acceptable for the observer to engage in atrocities (Steutur and Wills 2009, p. 19). Hobart (2007, p. 190) concurs, adding that that stereotyping the 'enemy' may make the case of the perpetrators of violence appear common cause. He notes that 'Particular assumptions about space, time narrative, personhood, agency, and causation are distinctive of different genres; and are combined in ways that, through reiteration, give a sense of naturalness and self-evident truth to what are carefully constructed and inherently mediated accounts'. In the case of the state-owned press, assumptions about the opposition being responsible for introducing violence into Zimbabwean politics and their reiteration in the state-owned press could not only engender feelings of ill will against the opposition, but also justify its annihilation.

Like the state-owned press, the privately-owned press was equally selective in its attribution of election violence. It overwhelmingly blamed Zanu-PF and state security agencies for perpetrating election violence while remaining silent about the transgressions of the opposition. However, the culpability of the two could not have been identical given that the opposition did not control the instruments of power. Examples of news headlines where the privately-owned press routinely and selectively blamed the ruling Zanu-PF and state aligned institutions include: 'Zanu (PF) brings Marondera to a halt' (Daily News 22 May 2000, p. 2); 'Sekeramayi threatens commercial farmers' (Daily News 23 May 2000, p. 2); 'Violence: War vets, Zanu (PF) supporters remanded in custody' (Daily News May 2000, p. 2); 'CIO, ZNA join farm invasions' (The Zimbabwe Independent 13 July 2000, p. 10); 'Zanu (PF) supporters burn MDC vehicle in Muzarabani' (Daily News 13 July 2002, p. 15); 'Zanu (PF) trio charged with murder of two MDC activists' (Daily News 1 February 2002, p. 3); 'Zanu (PF) forces people to rally', Zanu (PF) trio charged with murder of two MDC activists' (Daily News 1 February 2002, p. 3): 'Militia seize hundreds of ID cards' (The Zimbabwe Independent 8 February 2002, p. 1); 'Government sets up 146 militia bases' (The Zimbabwe Independent 1 March 2002, p. 4); 'Zanu (PF) hijacks church to boots votes, political rallies disguised as prayer meetings' (The Financial Gazette 17 January 2002, p. 8); 'Millions forced to buy Zanu (PF) cards: Extortion sees party raking $\$ 500 \mathrm{~m}$ in three months' (The Financial Gazette 24 January 2002, p. 6); 'Trigger happy cops ignite orgy of violence in Bulawayo; Police, Zanu (PF) gang up to thwart MDC rally' (The Financial Gazette 24 January 2002, p. 9); and 'Zanu (PF) unleashes militia on Byo' (The Financial Gazette 7 February 2002, p. 20). 
As can be seen in the some of the news headlines above, naming the political affiliation of the perpetrators of election violence (i.e. Zanu-PF or state agents) was intended to ensure that the question of who was responsible for election violence was not left open in the minds of the readers. Hobart (2007, p. 197) notes that using the active mood is a key aspect of identifying perpetrators. It has the effect of making the named appear as 'the agent that disrupts the natural order' while 'exnomination', which is the contrary process, has the effect of 'masking the agent that disrupts the natural order'.

In the specific context of Zimbabwean elections, the privately-owned press's identification of perpetrators of election violence was preceded by demands for 'concrete action' to be taken against the perpetrators. This was so as to 'bring a semblance of normalcy to our tormented nation' (The Financial Gazette 25 May 2000, p. 8). This would be followed by proposals for a raft of drastic measures such as that: 'the police must swiftly crack down on anyone perpetrating violence' (The Financial Gazette 8 June 2000, p. 8); 'SADC must stop collaborating with rogue rulers (The Zimbabwe Independent 22 February 2002, p. 6); 'Mugabe must step down' (Daily News 23 March 2002, p. 4); or simply that observers should rein in Zanu-PF lest the elections be 'rendered null and void' (The Financial Gazette 8 June 2000, p. 8); and 'We need to identify the impediments to a free and fair election so that they become a matter of public record' (The Zimbabwe Independent 8 February 2002, p. 6). The naming of the perpetrator was almost always followed by a call for some form of sanction to be imposed on the perpetrators of election violence. This is consistent with Hobart's observations that the press tends to frame news in such a way as to 'anticipate and imply the need for appropriate future action' (Hobart 2007, p. 200).

It could be argued that the privately-owned press's use of naming as a strategy to deter would-be perpetrators of election violence is consistent with its espoused watchdog function. The statement by Wisdom Mudzungairi, acting editor of the privately-owned daily newspaper was instructive in this regard. Mudzungairi argued that if his newspaper did not cover election violence, that would be an abdication of its 'role as the watchdog in society' (interview with Wisdom Mudzungairi, 15 May 2015). Reporting on elections was considered part of his newspaper's mandate to give a voice to the voiceless, curb election violence and promote peace, thus accentuating the sanctity of life. By blowing the whistle on election violence the privately-owned press accentuated a liberal human rights discourse pivoted on the watchdog role of the press. While exposing election violence was a noble thing, selective application - as was the case by the privately-owned press - could have heightened animosity between the opposition and the ruling party, thereby sowing the seeds of bitterness in a divided society. 
It would not be farfetched to conclude that the selective reporting of election violence might have contributed towards the hardening of views among ruling party supporters, particularly given the gamut of derogatory epithets directed at the ruling party. Such epithets include 'mobs', terror squads', 'thugs' and 'gangs', while sparing the opposition from the same labels. It should however be noted that although the state-owned press used similar labels against the MDC, these were more tendentious in the privately-owned press, which deployed a liberal human rights lens. Examples of news headlines which portray this include: 'Zanu (PF) gangs on a looting spree' (The Zimbabwe Independent 18 February 2002, p. 2); 'Zanu (PF) mobs burn down MDC polling agents' homes' (Daily News 25 March 2002, p. 18); 'Zanu (PF) mob attacks MPs house' (Daily News 28 February 2002, p. 3); 'Rampaging Zanu (PF) supporters loot, damage house in Chinhoyi' (Daily News 27 February 2002, p. 19); and 'Rural folk flee orgy of terror' (Daily News 16 May 2000, p. 1).

Derogatory phrases such as 'gangs' and 'mobs' connote criminality, while the manner in which the violence is executed, such as 'rampaging' and 'orgy of terror', evoke barbarism and senselessness. Such phrases were pivoted on some form of moral absolutism (Napier \& Jost 2008) in the sense that they normalised hateful attitudes towards the ruling party, while 'harvesting' sympathy on behalf of the opposition. The problem with such epithets, particularly in politically fragile societies where every group of people is convinced about the correctness of their assumptions and the sanctity of their positions, is that they can breed intolerance. In the privately-owned press, images of opposition victimhood were mainly refracted through the prism of appeals and calls for the international community to intervene in Zimbabwe. Victims of Zanu-PF violence were constructed as helpless, hapless and harmless. Appeals for international intervention were framed from a humanistic angle. For instance, in a story headlined: 'MDC appeals for help to end violence', The Zimbabwe Independent (22 February 2002, p. 2) reported that the 'besieged' MDC leader Morgan Tsvangirai was appealing for international intervention as 'mobs loyal to President Mugabe stepped up their retribution against the party's supporters'. The MDC complained that its supporters were 'being hounded and hunted down, kidnapped, tortured and killed by Zanu (PF) militias'. The story gave a blow-by-blow chronicle of MDC supporters who had fallen victim to Zanu-PF's violence. Framing election violence as one-sided ensured that the alleged victims of Zanu-PF violence elicited sympathy from the readers while at the same time it magnified the callousness of the ruling party. Journalists in the private press justify using words such as 'mobs', 'rampaging', 'gangs', and 'orgy of terror' on the grounds of professional considerations and their ability to capture reality at that time. While the effect of these epithets on the readers is debatable, the use of such labels suggests an objectivist, absolutist construction 
of reality. In this construct the privately-owned press placed a premium on the sanctity of their versions of the truth, even if it meant disregarding the fact that the opposition was neither a hapless victim nor a bemused bystander with regards to election violence. One editor was convinced that 'There is no other way of describing them (the perpetrators of violence)', adding that the reason for using such labels was to bring the perpetrators to account (E2, interview, 11 May, 2015, Harare). Another editor added that the use of such sharp language was consistent with the journalistic genre and served to vividly portray events. He pointed out that:

Instead of just saying 'Zanu (PF) officials or supporters beat up MDC supporters' we will use strong language and call them thugs because that's what they are. If you are using extra-legal means to gain, eh, eh, an electoral advantage, you are unleashing violence we call it terror, depending on the scale. We use the words 'violence', 'terror', 'intimidation' depending on the scale. If it's widespread, it's terror. If it's isolated, it's intimidation. If it's systematic, it's violence. So we use those words depending on the prevailing conditions on the ground. We call it terror when it's all over the place.

Interview with Dumisani Muleya, 11 May, 2015, Harare

Such an absolutist stance found expression in language consistent with the watchdog function whose hallmarks are adversarial journalism (Goran \& Otsman 2013, p. 309). Former editor of the Daily News Geoff Nyarota acknowledges this moralist stance of the press when he notes that journalists always like to occupy the high moral ground, lecturing politicians on what is good and bad. Nyarota notes that:

So they will say if I say if 'five people were killed' the politician may miss the point, but if I say there was an orgy in their constituency the politician will...Their intention is good and noble but sometimes it can be misunderstood because the purist will say, five people cannot be an orgy, ladies and gentlemen.

Interview with Geoff Nyarota, 11 May 2015, Harare

While the good intentions of journalists cannot be completely dismissed, it would be uncritical to accept the view that the intentions of the press are misunderstood. This is particularly so given the fact that journalists in Zimbabwe are hyperpolitical, almost to the extent that the fine line between professionalism and political activism becomes blurred during election time. As one editor pointed out 
journalists are 'political creatures' with 'political aspirations' and the temptation to 'root for political parties in their personal capacities is reflected a lot in stories' (Vincent Kahiya, interview, 11 May 2015). This clearly runs against the grain of the objectivist stance of the privately-owned press and demonstrates that the press became a tool to delegitimise the ruling party by accentuating the victimhood of the opposition.

This image of victimhood was further intensified as seen through a human interest frame in which alleged victims of election violence were literally milked for sympathy while the ruling party was portrayed as evil. An example of news headlines which illustrate this include: 'Police raid widow's home' (The Zimbabwe Independent 8 February 2002, p. 4); 'Observer pastor assaulted' (Daily News 13 March 2002, p. 4); 'War veterans murder guard, assault farmer' (Daily News 18 March 2002, p. 2); 'Youth terrorise Chivhu villagers' (Daily News 8 February 2002, p. 12); 'War vets attack nurses' (Daily News 25 March 2002, p. 2); 'Zanu (PF) youths stone Motswana woman's car' (Daily News 6 January 2002, p. 6); and 'Villagers flee violence to the cities' (The Financial Gazette 25 February 2002, p. 2).

The thread running through these examples of victimhood (widow, pastor, nurse, guard, farmer, villagers, and women) is their vulnerability or presumed innocence. ${ }^{2}$ This 'parasitic' tendency is best illustrated in 'Orphan's house damaged in clashes' (Daily News 22 March 2000, p. 2). This story highlighted the plight of a teenage orphan, Tawanda Neshiri, whose house was allegedly damaged by war veterans and 'suspected Zanu (PF) youths' in the high density suburb of Budiriro. ${ }^{3}$ The story is saturated with humanistic rhetoric intended to trigger the reader's sympathy by accentuating the callousness of the tormentors. The victim's plight is graphically illustrated. The damage to the house is extensively covered in a riveting and emotional narrative style that leaves the reader completely bewildered. The victim is allowed to relieve his ordeal in a testimonial style, thereby heightening the emotions of the readers. He is reported to have said:

They (Zanu (PF) supporters) threw stones at the house and one of them threw a ball of fire through one window... They later went around telling residents to stay in-doors. Those who refused were taken to Hunzvi's Surgery where they were allegedly assaulted.

The use of the pronoun 'they' is a way of 'othering' the alleged perpetrators of election violence and this widens the gulf between the 'evil' perpetrators and the

2 Although the white farmers belong to an economically powerful group in the specific context of farm occupations they were constructed in the international media and local privately-owned press as victims of 'Mugabe's tyrannical rule'.

3 Budiriro is a high density suburb in the capital city Harare. 
readers. Through the victim's narrative, readers learn about the ubiquity of ZanuPF's 'brutality' and 'tyranny'. Readers are further told that victim's father died in 1994 and his mother 'succumbed in the same month four years later'. The story was accompanied by a picture of the teenage boy in school uniform carrying a school bag, a vivid depiction of this alleged victim of Zanu-PF's election violence. The emotive style of the story eschews the rational, thereby generating intensely negative feelings against the ruling party. The default line seems to be that if Zanu (PF) can treat the most vulnerable in society like this how about the rest of the population'? As a discursive strategy, the power of humanistic rhetoric lies in suspending rationality by saturating readers with humanist values such as compassion, reason, love and the greater good so that the reader is compelled to empathise with the alleged victim (Harvey 2000). Humanistic rhetoric compels the reader to be outraged by the actions of the perpetrator and intensely sympathetic towards the victim, what Herman and Chomsky (1988, p. 43) have described as 'worthy victims'. The problem with humanistic rhetoric is that its emotive appeal may blind the reader to reason. Furthermore, it is a parasitic narrative which commodifies the weak, the meek and vulnerable in society by constructing simplistic binaries of 'Devils' and 'Angels' while complex issues fall through the cracks. Such oversimplification plays host to episodic frames and sensational headlines that have more sound than substance.

\section{If it Bleeds, It Leads: The Use of Apocalyptic Headlines}

The private press's reportage on election violence was couched in apocalyptic prophecies in order to draw the attention of local and international public. During elections life was portrayed as short and brutish thereby creating the impression that violence was omnipresent. Examples of such news headlines include: 'Brutal attack leaves MDC officials in coma' (Daily News 27 February 2002, p. 3); 'Zanu (PF) gangs on looting spree' (The Zimbabwe Independent, 18 January 2002, p. 2); '16 die in Zanu (PF) terror campaign' (Daily News 9 February 2002, p. 1); 'Zanu (PF) unleashes militia on Byo' (The Financial Gazette 14 February 2002, p. 2); 'Terror squads camp of farms' (The Financial Gazette 7 February 2002, pp. 1-51); and 'MDC supporters hacked to death' (Daily News 1 February 2002, p. 2). Phrases such a 'looting spree', 'terror campaign', and 'unleash', connote the senselessness of violence while 'brutal' and 'hacked to death' denote extreme viciousness. The motive behind such representation was to elicit and sustain attention and outrage from both the local and international public. A story headlined 'Agency warns on genocide' (The Financial Gazette, 28 February 2002, p. 5) demonstrates the hyperbolic constructions of election violence news in the private press. The story quoted the USA-based Genocide Watch Group speculating that 'Zimbabwe 
could slide into genocide' ahead of the presidential elections in March 2002. The group is reported to have said: 'early warning signs for politicide (mass political killings) and possibly even genocide in Zimbabwe' had 'reached stage six which is considered the final'. Furthermore, the US and the European Union were reported to have warned President Mugabe that they would use 'military intervention if the situation deteriorated further' (Financial Gazette 28 February 2002, p. 5). Although there was undoubtedly election violence in Zimbabwe, arguing that the situation was anywhere near genocide was 'over the top'. Group Editor of The Financial Gazette, Sunsley Chamunorwa, believes that apocalyptic headlines such as 'no one should die for any politician'. He added that the headline 'Agency warns of genocide' is entirely appropriate because fears of ethnic cleansing triggered memories of Gukurahundi ${ }^{4}$ (Sunsley Chamunorwa, interview 11 May 2015). This suggests that The Financial Gazette used hyperbolic terms in order to sound alarm bells about the ruling party. The intention was to forestall the worst possible scenario rather than wait for disaster to strike, on the basis that prevention is better than cure. This is consistent with the classical perception of the press as watchdog and public sentinel (Norris, 2010). However, it could be argued that raising the spectre of another Rwanda was a discursive strategy beyond the realm of the watchdog function, as it was a means to instigating a military intervention in Zimbabwe, a familiar trope used by hegemonic powers to meddle in the affairs of sovereign nations.

\section{Provokes Violence, Zanu-PF Reacts}

Although the image of Zanu-PF was predominantly that of an innocent victim of MDC violence, there were occasional discursive slippages in the state-owned press which unwittingly betrayed this as a façade. It was often reported that the MDC was largely responsible for 'triggering the violence' (The Sunday Mail 4 February 2000, pp. 1-4) while Zanu (PF) or the state 'reacted' or 'retaliated' (The Herald 23 March 2000, p. 1) in order to restore law and order. Examples of news headlines which support this are: 'MDC committed most of political crimes' (The Herald 16 March 2002, p. 1); 'MDC perpetrates more violence on the ruling party' (The Sunday Mail 11 June 2000, p. 5). The words in bold suggest the existence of more than one agent, meaning that the MDC could not have possibly perpetrated violence alone. The Sunday Mail story (11 June 2000, p. 5) headlined 'MDC perpetrates more violence on the ruling party' is illustrative in this regard. The newspaper sought to rebut allegations by an Amnesty International report that Zanu-PF was responsible for

4 Reference to the civil war in the early 1980s during which about 20000 civilians were killed in a government-sponsored military operation in Matabeleland and the Midlands. 
most of the violence in the run-up to the 2000 general elections. The newspaper quoted police officials who refuted the Amnesty International report, adding that the MDC was responsible for the lion's share of electoral violence in the country. The newspaper accused the Amnesty International report of being 'one-sided', noting that it chronicled in greater detail incidents of violence perpetrated against members of the MDC but was silent on violence against members of the ruling Zanu-PF party.

The Sunday Mail gave a litany of incidents of election violence allegedly perpetrated by the MDC dating back to February 2000 in order to prove that the MDC was not 'an innocent bystander' as far as election violence was concerned. In rationalising the view that the MDC had introduced political violence, the blame discourse congeals into one of moral equivalence. In this perspective election violence was constructed as being simply a case of members of different political parties 'beating each other' or as 'political clashes' between different political parties (Caesar Zvayi interview, 7 May, 2015, Harare). The acting editor of the paper, Mabasa Sasa, was more circumspect than Zvayi, choosing to accentuate the frame of moral equivalence by suggesting that both MDC and Zanu-PF were to blame for starting violence. Sasa further added that the MDC had a greater propensity to commit election violence because it stood to benefit financially, and through what he termed the 'politics of pity' (Mabasa Sasa interview, 15 May, 2015, Harare). From a state press point of view, the fact that the MDC 'profits' from election violence implies that the opposition party has more incentive for starting violence than the ruling party. Profiting from violence is no different from starting the violence. This implies that it was in the national interest for the state-owned press to project the MDC as a perpetrator of election violence since it was the only party that stood to benefit from election violence.

\section{Mystification: Fighting against 'invisible' forces}

A story published in The Herald (12 June 2000, p. 8) reveals the rationale for ZanuPF's 'retaliatory violence' narrative in the comments of war veteran Mau Mau, Zanu-PF parliamentary candidate for Harare East in the 2000 general election. Mau Mau, who was addressing a rally in Harare, is reported to have commended his supporters 'for not engaging in violence in the constituency in the count down to the elections, but said they would retaliate if provoked by the opposition' (emphasis added). Border Gezi, then Zanu-PF Mashonaland Central provincial chairperson accompanying Mau Mau, made a revealing statement. Gezi is reported to have said that '...the whites whom we defeated were now coming back through the back door through black puppets. This time they are using a puppet, Morgan Tsvangirai, but we know that it is them. Kana torova tsuro tinorova nedenhe racho 
(when we try to beat a hare hiding behind bushes we will not discriminate the hare from the bushes)'. The statement by Gezi, then a senior member of Zanu$\mathrm{PF}$, is crucial to understanding the instrumental logic of election violence and its mediation in the state owned-press. The fact that Zanu-PF believes that it is fighting not the MDC but a formidable and invisible force is significant as it shapes the discursive constructions of election violence in the state-owned press. This is seen as not only inevitable under the circumstances, but also as a legitimate tool for repelling neo-colonial forces. The view that Zanu-PF was battling bigger forces was made more succinct by President Mugabe. Addressing the $43^{\text {rd }}$ Ordinary Session of his party's Central Committee soon after the 'close shave' of the 2000 general elections, in which the party obtained 63 seats against the MDC's 57, Mugabe reminded his members that:

Often a myth is peddled that Zanu-PF lost to a nine-month-old opposition party. Nothing can be further from the truth. Whilst we expect our enemies to peddle such a myth, we should never allow it to take root in our minds. Such a misconception encourages us to underestimate the forces ranged against us, and to underplay the significance of our hard earned victory. The MDC should never be judged or characterised by its black trade union face; by its youthful student face; by its salaried black suburban junior professionals; never by its rough and violent high density lumpen elements. It is much deeper than these human superficies; for it is immovably and implacably moored in the colonial yesteryear and embraces wittingly or unwittingly the repulsive ideology of return to white settler rule. MDC is as old and as strong as the forces that control it; that converge on it and control it; that drive and direct; indeed that support, sponsor it. It is a counter-revolutionary Trojan horse contrived and nurtured by the very inimical forces that enslaved and oppressed our people yesterday.

Mugabe 2001, pp. 88-89

Although Mugabe's statement unpacks the MDC it also has the effect of creating a mystique about the opposition claiming that it is harboured by unknown forces and 'hides behind the bushes'. The point seems to be not to underestimate the strength of your enemy. The rationale for using excessive force to liquidate the MDC was because of the perception that the opposition party was an enemy 'hiding behind bushes'. Hence the state-owned press constructed discourses that legitimised violence against the MDC. The mystification of the MDC's strength implied that the opposition party was constructed not as a minion but as a very treacherous force that needed to be crushed by all means necessary. The view that 
the MDC is only a front of the West and that there were invisible forces behind much of the election violence in Zimbabwe was echoed by Mabasa Sasa. He pointed out that 'there are outsiders who are prepared to finance Zimbabweans to fight each other' (Mabasa Sasa, interview 15 May, 2015, Harare). The perception that there are invisible forces behind election violence has forced the state-owned press to take a hardline stance in defending the ruling party's position in relation to election violence. Mabasa Sasa explains thus:

... So when faced with threats such as these external threats, this external interference, this meddling in our politics to try and destabilise us as a country, naturally, we, we have the mandate to defend those values that are expressed in our independence of 1980. So naturally, we become more robust in defence of our national interest, when faced by such threats, ahmm, not just in a defensive manner, we have to go offensive as well in defence of our country. So yeah, over the years, the, as this external threat became more and more apparent we too have become more robust in our responses to that threat. Ah, with, our intent being, ah, upholding the integrity of our state.

Interview with Mabasa Sasa, 15 May, 2015, Harare

Zvayi corroborates Sasa's sentiment about the existence of a third force, reasoning that although Zimbabweans are generally peaceful people, during elections they become violent because of outsiders who fund people to engage in violence (interview with Caesar Zvayi, 7 May, 2015, Harare). In the larger discursive scheme, projecting Zanu-PF as responding to invisible external threats against national sovereignty could possibly have further polarised the nation. Robust and offensive tactics would ordinarily encompass discursive strategies that tend to justify violence against the opposition and its alleged external funders, as has been demonstrated in the example of Border Gezi above. At the same time, constructing the ruling party as being engaged in a mortal fight with invisible forces helps to minimise the ruling party's moral culpability. This also sanitises the backlash against the supposed political fronts of external forces, which in this case would be the opposition.

\section{Both Parties are to Blame: A False Moral Equivalence?}

The mystery about the existence of a much bigger and invisible force lurking behind the opposition gave way to discourses about power symmetry in the stateowned press. This found expression in a false moral equation whereby Zanu-PF and the MDC were portrayed as being equally culpable for election violence. 
Examples of news headlines which attest to this are: 'MDC-Zanu (PF) blamed for flare-up of violence' (The Herald 23 May 2000, p. 1); and 'Fresh clashes in Karoi' (The Herald 21 March 2002, p. 8). In a story headlined 'Political tension caused by extreme positions', The Herald (19 May 2000, p. 7) reported that the political tension prevailing at the time was a result of the 'extreme positions adopted by the two main rival parties, Zanu (PF) and the Movement for Democratic Change'. Quoting a political commentator, Dr. Admore Kambudzi from the University of Zimbabwe, the newspaper claimed that the violence stemmed from the MDC's 'super ambition' to form the next government and Zanu-PF's 'over-reaction' to the rejection of the draft constitution in the February 2000 referendum. Blaming the 'extreme positions', both parties rationalised violence thus creating the impression of 'moral equivalence', (Carr 2000, p. 84). Conscripting a supposedly knowledgeable expert from the university lends legitimacy to the narrative of equal blame. Constructing both parties as being equally to blame meant that nothing could be done to end election violence. It could be argued that the frame of moral equivalence has to do with the institutional processes of news-making, such as the need to have a semblance of balance and impartiality and objectivity in what (Toscano 1979, p. 177) called 'dubious neutrality'. Thus the ruling party, which is constructed as an innocent victim, became an active agent in a power symmetry. This clearly demonstrates how the meaning of election violence was contingent on who was invoking it (Hall 1997, p. 9). Hall aptly observes that meanings do not simply exist but are actively constructed through selection, inflection, inclusion and exclusion. In the specific context of Zimbabwean presidential and parliamentary elections, the meaning of election violence became elastic to suit the political agendas of the different press camps. This shows how discursive constructions of electoral violence in the state-owned press are circumscribed by tensions between ideological and professional considerations (Machin 2008, p. 64). Such considerations played an important role in determining who was blamed for violence, how they were constructed and what was said as well as what was not said about them.

\section{CONCLUSION}

This article has discussed the discursive construction of electoral violence in the state-owned and the privately-owned press in Zimbabwe during the presidential and parliamentary elections held in Zimbabwe between 2000 and 2002. The main observation was that the two press camps produced competing discourses on election violence. Although the actual role of the press in election violence could not be conclusively determined, it was apparent that both sides of the press divide deployed anti-democratic discursive practices which have the 
potential to engender a culture of intolerance. The meaning of election violence became contingent on who was invoking it, with the state-owned press blaming the MDC for election violence, while the privately-owned press laid the blame on the governing party, Zanu-PF. Thus, election violence became the site for meaning contestation and a tool for delegitimising political opponents while maintaining silence on the transgressions of preferred political players. In the ensuing dialogue of the deaf, the meaning of election violence became elastic depending on who was the victim or perpetrator or who stood to benefit from it. It became clear that, contrary to the view that media simply reflect reality and that meanings are free-floating, meaning is socially constructed and deeply implicated in relations of power. As a consequence, election violence was viewed through a binary prism whereby the perpetrator was either the ruling party and state agents, or the opposition, thereby obliterating the middle ground. In the larger discursive scheme, competing and incompatible versions of election violence reflect ideological polarisation. These were crystalised through, on the one hand, the privately-owned press's liberal human rights model of journalism, epitomised by accentuating the watchdog function of the press; and on the other hand, the state-owned press's espoused journalism model of national interest put a premium on state sovereignty and the necessity of rebuffing imperial interests. That the press can construct contradictory versions of election violence is not only a cause for concern, but also has wider implications for democracy.

\section{REFERENCES}

Akpabio, E 2011, 'Framing them in order to hang them?' Journal of International Communication, vol. 17, no. 1, pp. 37-49.

Alvesson, M, \& Skoldberg, K 2009, Reflexive methodology: new vistas for qualitative research, Sage Publications, London.

Anderson, D 2003, 'Kenya's election 2002: dawning of a new era?', African Affairs, vol. 102, no. 407, pp. 331-342.

Berger, G 2009, 'Theorizing the media-democracy relationship in Southern Africa', Gazette: The International Journal for Communication Studies, vol. 64, no.1, pp. 21-45.

Carr, M 2010, 'Moral equivalence and the "Slavador Option"', New Politic, (Summer), pp. 84-92.

Chouliaraki, L \& Fairclough, N 1999, Discourse in late modernity: rethinking critical discourse analysis, Edinburgh University Press, Edinburgh.

Fairclough, N 1995, Critical discourse analysis and the study of language, Longman, London. 
Ferret, G 2000, ‘Opposition warning to Mugabe', BBC World News (30 September 2000) Available at <http://news.bbc.co.uk/2/hi/africa/950338.stm $>[15$ December 2015]

Floss, D \& Marciankowski, F 2008, 'Do media news frames reflect a nation's political culture?' Working Paper No. 25. National Centre of Competence in Research (NCCR) Challenges to democracy in the $21^{\text {st }}$ Century, viewed at 19 June 2015, http: / / www.nccr-democracy.uzh.ch/publications / workingpaper/pdf/ WP25.pdf

Foucault, M 1972, The archeology of knowledge, London, Tavistock.

Foucault, M 1980, Power/Knowledge: selected interviews and other writings 1972-1977, Vintage Books, New York.

Galbin, A 2014, 'An introduction to social constructionism', Social Research Reports, vol. 26, pp. 82-92.

Goram, E \& Ostman J 2013, 'Cooperative or adversarial? journalists' enactment of the watchdog function in political news production', International Journal of Press/Politics, vol. 18, no. 3, pp. 303-324.

Gray, DE 2009, Doing research in the real world, Sage Publications, London.

Hall, S 1992, 'The West and the rest' in S Hall \& G Bram (eds.) Formations of modernity, Polity Press / The Open University, Cambridge.

Hall, S 1997, 'The Work of Representation' in S Hall (ed.) Representation: cultural representations as signifying practice, Sage Publications, Thousand Oaks.

Hallin, DC \& Mancini, P 2004, Comparing media systems: three models of media and politics, Cambridge University Press, Cambridge.

Harvey, J 2000, 'Media Coverage of the Zimbabwean Land Crisis', Deep South, vol. 6, no. 3, (Spring), pp. 1-4, Viewed 15 December 2013 http:/ / www.otago. ac.nz/ deepsouth/spring2000/harveyone.html

Herman, E \& Chomsky, N 1988, Manufacturing consent: a propaganda model, Pantheon Books, New York.

Hobart, M 2007, 'Round up the usual suspects: some radical implications of Indonesian and Euro-American media coverage of "terrorism" attacks', in H Nossek, A Sreberny \& P Sonwalkar (eds.) Media and political violence, Cresskill: Hampton Press.

Hobbs, M 2008, On discourse and representation: reflections on Michael Foucault's contribution to the study of the mass media, Paper Presented at the Australian Sociological Association, University of Melbourne, December 2008, viewed 15 May 2016. https://www.tasa.org.au/wp-content/uploads/2011/05/ Hobbs-Mitchell-Session-19-PDF.pdf

Ismail, JA \& Deane J 2008, ‘The 2007 general election in Kenya and its aftermath: the role of the local language media', The International Journal of Press/Politics, vol. 13, no. 3, pp. 319-327. 
Jorgensen, M \& Phillips, LJ 2002, Discourse analysis as theory and method, Sage Publications, London.

Khadiagla, G 2009, 'Reflections on the causes of election violence in Africa', Paper presented at EISA's fourth Annual Symposium. Johannesburg, 17-18 November 2009.

Koko, S 2009, 'Understanding election-related violence in Africa: patterns, causes, consequences and a framework for preventive action', Journal of African Elections, vol. 12, no. 3, pp. 51-88.

Kriger, N 2005, 'Zanu (PF) strategies in general elections, 1980-2000: discourse and coercion', African Affairs, vol. 104, no. 414, pp. 1-34.

Louw, E 2001, Media and cultural production, Sage, London.

Machin, D 2008, 'News discourse: understanding the social goings-on behind news tests' in Mayr, A (ed.) Language and power: an introduction to institutional discourse, Continuum Publishing Group, London.

Merilainen, TS 2012, Electoral violence as a side product of democratization in Africa: the cases of Nigeria, Kenya and Zimbabwe, Masters Thesis, University of Helsinki. Department of World Cultures, October 2012.

Motsamani, D 2010, When elections became a curse: redressing electoral violence in Africa, EISA Policy Briefing No. 1, March 2010, EISA, Johannesburg.

Mugabe, R 2001, Inside the third Chimurenga, Department of Information and Publicity, Harare.

Nossek, H Sonwalkar, P \& Sreberny, A. (eds.) 2007, Media and political violence, Hampton Press, Cresskill, NJ.

Onyebadi, U \& Oyedeji, T 2011, 'Newspaper coverage of post-election violence in Africa: an assessment of the Kenyan example', Media, War and Conflict, vol. 4, no. 3, pp. 215-230.

Pitsoe,V \& Letseka, M, 2013, 'Foucault's discourse and power: implications for instructionist classroom management', Open Journal of Philosophy, vol. 3, no. 1, pp. 23-28.

Sachikonye, L 1990, 'The 1990 elections: a post-mortem', Review of African Political Economy, vol. 48, pp. 92-99.

Sachikonye, L 2011, When a state turns on its citizens: institutionalized violence and political culture, Weaver Press, Harare.

Schlesinger, P 1991, Media state and the nation: political violence and collective identities, Sage Publications, London.

Shaw, IS 2009, 'Towards an African journalism model', The International Communication Gazette, vol. 71, no. 6, pp. 491-510.

Shilaho, WK 2013, 'Old wine in new skins: Kenya's 2013 elections and the triumph of the ancient regime', Journal of African Elections, vol. 12, no. 3, pp. 89-119. 
Sithole, M \& Makumbe, J 1997, 'The Zanu (PF) hegemony and its incipient decline' African Journal of Political Science, vol. 2, no. 1, pp. 122-139.

Steuter, E \& Wills, D 2009, 'Discourses of dehumanisation: enemy construction and Canadian Media Complicity in the Framing of the War on Iraq', Global Media Journal - Canadian Edition, vol.2, no. 2, pp. 7-24.

Stremlau, N \& Price, M 2009, Media, elections and political violence in Eastern Africa: A comparative framework, Annenberg-Oxford Occasional Paper in Communications Policy Research, London.

Toscano, PJ 1979, 'A dubious neutrality: the establishment of secularism in the public schools', Brigham Young University Law Review, vol. 2, pp. 177-211.

Vladisavljevic, N 2015, Media Framing of Political Conflict: A Review of Literature, MeCoDEM Working Paper Series, viewed 12 January 2016. http:/ / www. mecodem.eu/wp-content/uploads/2015/05/Vladisavljevi\%C4\%87-2015_ Media-framing-of-political-conflict_-a-review-of-the-literature.pdf

Voltmer, K 2010, 'Media. Government Accountability and Engagement', in Norris, P (ed.) Public sentinel: News media and governance reform, World Bank, Washington DC.

White, R 2004, Discourse Analysis and Social Constructionism, vol. 12, no. 2, pp. 7-16. Zhang, Y \& Wildermuth, BM (n.d.), 'Qualitative Analysis of Content', viewed 21 December 2015, https://www.ischool.utexas.edu/ yanz/Content_ analysis.pdf 